\title{
The Use of Computer Mediated Communication (CMC) in Distance Learning During Covid-19 Pandemic: Pros and Cons
}

\author{
Ika Novitaria Marani ${ }^{1 *}$ Ari Subarkah ${ }^{2}$ Adi Wijayanto ${ }^{3}$ \\ ${ }^{1,2}$ Faculty of Sport Sciences, Universitas Negeri Jakarta, Jakarta, Indonesia \\ ${ }^{3}$ Faculty of Science Education, IAIN Tulungangung, Jawa Tengah, Indonesia \\ *Corresponding author.Email: ika.novitaria@unj.ac.id,ikanovi1979@gmail.com.
}

\begin{abstract}
There has been a change in learning activities after Covid-19 became a global pandemic. The change occurring is, among others, that from face to face learning to distance learning through the online process, like the used of Computer-Mediated Communication (CMC). Accordingly, the use of CMC goes along with its pros and cons. Therefore, this study aims to find out how the use of CMC is in the implementation of distance learning and how the pros and cons are of the use of CMC in distance learning. This study employed a descriptive method with a survey technique. The data were collected using closed questionnaires distributed through Google Form to 324 students. The results show that $89.8 \%$ of students prefer face to face learning and only $10.2 \%$ of them prefer distance learning. The use of CMC is considered ineffective in such courses as swimming because students are required to practice, in addition to the written material delivered. Three factors cause the pros and cons in the use of CMC: internal factors, external factors, and contextual factors. External factors include time and family constraints, lack of supports from the surrounding environment, and financial problems. Meanwhile, the internal factors are related to discipline and the ability of students to manage their time wisely. Besides, contextual factors are more likely found on online applications that are not friendly to users, and lack of interactivity.
\end{abstract}

Keywords: Distance Learning in Higher Education, Computer-Mediated Communication (CMC), COVID 19 Pandemic.

\section{INTRODUCTION}

The COVID-19 pandemic occurring in 2020 has an impact on the world of education, from kindergartens to universities. To suppress the expansion of COVID-19, the government encourages all Indonesian citizens to stay at home in their daily activities such as work, study, and so on. This decision was made based on research stating that to decide on the spread of COVID-19, it was recommended to avoid meeting with more than 10 people (www.whitehouse.gov, n.d). Although the situation requires the students to be at home, the educators must ensure that teaching and learning activities continue. Thus, educators are required to design learning media as innovation by utilizing online media. In short, it can be said that with the COVID-19 or corona outbreak, this would be a great catalyst that spurs the world of education, for this pandemic can accelerate education in the era of the industrial revolution 4.0. This existence of pandemic spurs the world of education to utilize more information technology in its learning activities. Thus, the learning system carried out now utilizes information technology. Hence, it can be said that the world of education cannot be separated from the development of communication technology [2].

In this digital age, there has been the development of information technology that can facilitate the access to information through the Internet which blurs the boundaries between space and time. This change is marked by the development of learning media influenced by information technology or internet technology such as the use of e-learning, internet, e-mail facilities, and others concentrating on the use of computers [3]. This computerbased technology is one of the tools used in supporting 
learning activities during this pandemic to help Distance Learning activities.

In the distance learning system, there is a distance that separating between lecturers and students. Thus, direct interaction between individuals does not take place but is mediated by a digital platform [4]. The pattern of computer-mediated communication (CMC) changes the nature of human communication interactions from face to face meetings to meetings in digital space in the learning process. Seen from a communication perspective, communication patterns in the current digital era, when CMC takes over communication interactions between individuals as more digital platforms, makes communicating remotely via text, audio, or video-based channels easier [5]. CMC began to receive attention from a variety of research literatures. CMC research studies focus on the quality of group decision making [6] [7] (Shu-Chu Sarrina Li, 2007), interaction analysis [9] [10], member participation [11], the effects of time and space on group interactions [12] [13], and the quality and dynamics of interactions [14] [15].

Likewise in Indonesia, when a pandemic entered Indonesia, the learning from home policy began to be implemented on March 9, 2020, to prevent the spread of COVID-19 or coronavirus disease (Pendidikan, Kabupaten, Pendidikan, Tinggi, \& Kesehatan, 2020). Following the circular up, all tertiary institutions are required to issue policies on the online learning process for their students. Lectures using the distance learning/online system potentially trigger social inequality which has an impact on the quality of student learning. Thus, this form of learning has become a debate in many circles, both lecturers and students, because in its implementation, both lecturers and students felt panic.

Many problems become obstacles in the online learning process such as fairness. It is because lecturers and students need to adapt to the sudden transition in the distance learning process. Moreover, every student has different abilities and experiences with one another. Therefore, this study aims to find out how the implementation of $\mathrm{CMC}$ in distance learning and the pros and cons of what is encountered in the use of CMC during distance learning.

\section{LITERATURE REVIEW}

\subsection{Distance Learning}

The concept of distance learning has a new meaning with the development of technology and information. The existence of distance learning depends on the learning media used while the learning media always changes along with technological developments. Therefore, the development of the world of information technology affects the world of education where learning based on information and communication technology has changed the traditional pattern of learning systems into media patterns. Accordingly, the change in technology also causes a change in the learning process.
The concept of distance learning in tertiary institutions, teaching takes place under conditions where lecturers and students are separated by physical location and time. Lecturers and students can be in different rooms, different buildings, different cities, different states, or even different countries. The goal to be achieved in distance education is to provide the same educational opportunities as those provided in traditional classroom teaching. The main factor in increasing interest in distance education is the ability of conducting direct and indirect teaching between lecturers and students made possible by technology [18]. Distance learning is defined as "the acquisition of knowledge and skills through mediated information and instruction, encompassing all technologies, and other forms of learning at a distance" [19]

Distance learning has characteristics distinguishing it from traditional learning that uses face to face meeting. They are: 1) separation of educators and students during the learning process, 2) the influence of education provider organization on the learning process, including the form of student evaluation, 3) the use of technology as the learning media to bring together educators and students in delivering material, information, or assignments, and 4) a two-way communication between educators and students, between students, as well as between educators and students [21].

All learning systems are intended to facilitate students in the learning process. Distance learning systems prioritize the role of media in the learning process, which accordingly also changes with the development of technology and communication. This is evidenced by the shift in the use of media that further facilitates the teaching and learning process and can bridge the gap that separates education providers from students. Distance learning is a practical part of education dealing with teaching where distance and time are critical attributes, in which educators and students separated by distance and/or time. Interactivity in the teaching under the constraints of time and distance is a variable that tends to be important to the success of distance learning.

\subsection{Communication Mediated Computer}

The rapid development of information and communication technology (ICT) enables the use of electronic media such as computers in disseminating information. In the field of education, the development of ICT is triggering the development of electro learning (e-learning). E-Learning is a concept in the learning process using ICT, especially using Internet-based media. The development of internet technology makes it easy for people to interact without being bound by time and space any longer. The presence of internet technology has pushed the education sector into a new era marked by the ability of the community to form a new civilization relying on technology and various virtual activities.

The Computer-Mediated Communication (CMC) study began to develop in 1987. CMC is referred to as a new medium of communication. The term new media refers to high-tech media based on digital, computer, and 
network-connected information. New media is media that apply technology in communication such as connected information using computers. The computer is not only a Personal Computer (PC) or Laptop device, but all computer-based devices such as PDAs, smartphones, tablets, and the like. CMC can be interpreted simply as communication that occurs between individuals using computer media or through a computer. CMC is described as communication mediated by interconnected computers, between individuals, or groups separated by time and space.

$\mathrm{CMC}$ in education is defined as "the process by which people create, exchange, and perceive information using networked telecommunications systems that facilitate encoding, transmitting, and decoding messages" (December, 1996). General characteristics of CMC are asynchronous and synchronous communication capacity, high interactivity, and multi-path communication. The advantage of using computer-mediated communication $(\mathrm{CMC})$ is that it can create a unique environment when conducting discussions by avoiding the limitations of conversation posed by face-to-face communication [27].

Several main differences distinguish the limitations of conversation during discussions between CMC and face-to-face: place dependence, time dependence, communication structures, and communication richness [26]. CMC is a virtual communication process using computer text data without face to face, thereby reducing the meaning of interpersonal relationships. CMC is also seen as a transfer of communication technology that brings direction to the use of computers as a medium in processing ideas/messages and information that are axiomatic (clearly true information) [28].

\subsection{COVID- 19 Pandemic}

COVID-19 is a contagious disease caused by acute coronavirus 2 or SARS-CoV-2) respiratory syndrome. This virus is a large family of Coronavirus that might infect animals. When attacking humans, Coronavirus usually causes respiratory tract infections, such as influenza, MERS (Middle East Respiratory Syndrome), and SARS (Severe Acute Respiratory Syndrome). COVID-19 is a new kind of coronavirus found in Wuhan, Hubei, China in 2019 [29]. Therefore, this Coronavirus is named Coronavirus disease-2019, or in short COVID-19. COVID-19 has since been found to be widespread to the extent that it has resulted in a global pandemic that continues until today. Symptoms of COVID-19 generally include fever at $38^{\circ} \mathrm{C}$, dry cough, and shortness of breath. In the worst case, it leads to human death. As of 19 April 2020 at 10:38:37 IWST, 2,329,539 confirmed cases were reported in 185 countries, with 160,717 deaths and 595,229 cured [30].

An impact of the corona (COVID-19) pandemic is how we can function as a community and society. One area that is affected substantially is the world of education at all levels [31]. Because of this pandemic, many educational institutions or schools are unable to carry out the teaching and learning process in face to face meeting.
This situation is expected to last for a long time and is not easy to handle. Given the long-standing effect of closing and maintaining social distance, it is important to change the learning process by formulating a strategic plan about online learning [32]. Online or digital learning is an alternative to continue the current teaching and learning process, especially in universities.

\section{METHODS}

\subsection{Population and Sample}

The population of study was the students of the Faculty of Sport Science, Jakarta State University who took part in lectures in the even semester, consisting of approximately 650 people. The sample consisted of 324 people who took practice and theory courses. The description of the sample filling out the questionnaire is distributed in Google Form.

\subsection{Research Procedure}

The data collection was carried out starting from the distance lecture, which was around March to June 2020 This study employed an online survey using Google Form distributed in the form of links to students who took several courses set by researchers through groups that had been formed by each of these courses. Students were asked to answer several questions related to strengths, weaknesses, threats, and opportunities related to the use of $\mathrm{CMC}$ in distance lectures during the pandemic using a close-ended questionnaire. The questionnaire contained questions about personal data related to their gender, age, semester, and residence. The data were collected in this study through Google Form. Therefore, generalizations and findings were limited to respondents who answered the questionnaire. This study only measured the opinions/perceptions of students and maybe not as an objective reality; it was completed voluntarily by students who took the specified courses during the distance learning.

\section{RESULTS AND DISCUSSIONS}

\subsection{Data Description}

This section descriptively describes the statements made by respondents regarding the use of $\mathrm{CMC}$ in distance learning during the pandemic period. From the statements, the strengths, weaknesses, opportunities, and threats of the use of CMC in students of the faculty of sports science can be known. There was a question asking them if they have CMC media (such as laptops), and $85.5 \%$ of them answered Yes while the rest, $14.5 \%$, answered No. Meanwhile, $98 \%$ of the respondents were able to operate the CMC media and only $2 \%$ who was not.

There were several applications used in distance learning using CMC: WhatsApp (25.9\%), Google Classroom (21.6\%), Edmodo (22.8\%), Zoom (20.4\%), and email 
(9.3\%). As many as $84.5 \%$ of respondents answered No and $15.5 \%$ of them answered Yes to a question asking whether or not they had difficulty in using the application, $68.7 \%$ of the respondents could receive and understand information (related to material or assignments) submitted by the lecturer and $31.3 \%$ of them said that they could not.

Ninety point four percents $(90.4 \%)$ of respondents said that there was an interaction (communication) between lecturers and students during distance learning and only $9.6 \%$ of them answered No. Meanwhile, $49.5 \%$ agreed that the use of $\mathrm{CMC}$ in distance learning is effective and the rest $(50.5 \%)$ disagree with it. Ninety eight percent $(98 \%)$ of the respondents prefer face-to-face learning process and only $2 \%$ of them liked distance learning. The data described above are summarized and presented in the following table:

Table.1. Summary of Questionnaire Data Description of the Use of CMC

\begin{tabular}{lcc}
\hline \multicolumn{1}{c}{ Statement } & Yes & No \\
\hline $\begin{array}{l}\text { Having a device used for distance } \\
\text { learning }\end{array}$ & 85.5 & 14.5 \\
$\begin{array}{l}\text { Being able to operate CMC } \\
\text { Facing difficulties in accessing } \\
\text { applications used in CMC media }\end{array}$ & 15.5 & 84.5 \\
$\begin{array}{l}\text { Receiving and understanding } \\
\text { information (related to material } \\
\text { or assignments) submitted by the } \\
\text { lecturer }\end{array}$ & 68.7 & 31.3 \\
$\begin{array}{l}\text { Having interaction } \\
\text { (communication) between }\end{array}$ & & \\
$\begin{array}{l}\text { lecturers and students during } \\
\text { distance learning. }\end{array}$ & 90.4 & 9.6 \\
$\begin{array}{l}\text { Using CMC in distance learning } \\
\text { effectively }\end{array}$ & 49.5 & 50.5 \\
Preferring distance learning & 2 & 98 \\
\hline
\end{tabular}

Table 2. Summary of the Use of Application in CMC

\begin{tabular}{lr}
\hline \multicolumn{1}{c}{ Application } & Percentage \\
\hline WhatsApp & 25.9 \\
Google classroom & 21.6 \\
Edmodo & 22.8 \\
Zoom & 20.4 \\
Email & 9.3 \\
\hline
\end{tabular}

Apart from the open-ended questionnaire, there were also closed questionnaire questions to follow-up the openended questionnaires to find out more reasons. Considering the results of the questionnaire, the difficulties encountered when using CMC applications in distance learning are:

"There are constraints due to network problems or an inadequate internet connection. This was because several regions in Indonesia still have difficult access to the internet such as Kalimantan, Sumatera, and also in Java".

There were several applications used during the distance learning using CMC: WhatsApp, Google Classroom, Edmodo, Zoom, and email. The most widely used applications used by lecturers in delivering the materials were WhatsApp and Google Classroom. Those applications were considered to be easier to use and be accessed by students both in the delivery of material and in the provision of assignments as well as affordable. For follow-up questions about whether they can receive and understand information (related to material or assignments) given by lecturers, respondents who answered No stated as follows:

"Information cannot be accepted for in the past even semester, there were many lectures on practice courses such as swimming and sciences. Those courses require direct practice to make them easier to understand. Besides, there were network/connection constraints causing the delivery of material provided intermittently".

The respondents further answered questions related to the advantages of distance learning using $\mathrm{CMC}$ as follows:

1) Students read more related to the assignment given and ask more questions about the material and assignments. 2) It is easier to access various distance learning applications used and is more flexible with the time and place of learning. 3) The use of technology suits the times. 4) It does not require transportation costs to campus.

Although distance learning using $\mathrm{CMC}$ has advantages, it also comes with its disadvantages. This can be seen from the respondents' statements, as follows:

1) By using distance learning, there will be more assignments, and 2) excessive use of Internet data quota. 3) Depending on internet technology and networks in using CMC media, the information will be cut off if there is no internet. 4) Moreover, for practice courses such as swimming and kneading, distance learning is considered very ineffective for students who cannot directly practice for these courses. 5) There is less interaction between students and lecturers and the material is not maximally conveyed due to network problems that occur.

Apart from the advantages and disadvantages of distance learning, there are also threats and opportunities. The threat of distance learning based on the respondents' answers is as follows:

1) There will be lack of socialization and increasing addiction to the use of media for a different purpose (playing games), 2) the possibility of cybercrime to take place, 3) lack of quality outcomes of the course especially the practice courses caused by lack of practice, 4) less creative students due to copy-paste 
practice, 5) excessive pressure for people who do not own the device, do not have much money to buy internet data quotas and 6) unable to operate the device or use the applications.

The face-to-face learning method is preferred by as much as $89.8 \%$ of the students compared with the distance learning method which was only preferred by $10.2 \%$ of the respondents. Most of the respondents prefer face-to-face lectures due to the following reasons:

1) A face-to-face system makes it easier to interact with other lecturers or students if some materials or assignments are not understood yet; 2) Practice course such as swimming and sports massage can be directly exemplified and practiced immediately after receiving the material in a face-to-face system; 3) Information in the form of material is easier to accept and understand its meaning; 4) Socialization can occur with lecturers and peers.

\subsection{Discussion}

During the COVID 19 pandemic in Indonesia, distance learning became a new thing that must be done in the field of education, including universities. Therefore, a study was conducted to find answers about how the implementation of distance learning using CMC and the pros and cons of what happened to distance learning used are in tertiary institutions, especially among students of Faculty of Sports Science, Universitas Negeri Jakarta. The development of communication technology is increasingly fast and growing. This certainly has implications to the world of education, where electronic media such as cell phones are used. CMC is a favorite channel in onlinebased learning [33]. This can be seen from the results of the research suggesting that as many as $85.5 \%$ of students have CMC devices and $98 \%$ of students can operate these devices.

$\mathrm{CMC}$ is one of the main bases to support the distance learning process. CMC, especially its online platform, is used to assist distance learning. There were several types of online platforms used in distance learning at Universitas Negeri Jakarta: WhatsApp, Google Classroom, Edmodo, Zoom, and email. The 3 (three) most widely used platforms were WhatsApp (25.9\%), Edmodo (22.8\%), and Google Classroom (21.6\%). These results indicate that some lecturers give lectures using a platform that is easy to use in the distance learning process. The choice of application platforms by lecturers tends to be different as well as based on text, audio, video, and a combination of the three. Paying attention to face-to-face communication as the top of the media richness hierarchy, then the platform characteristics that can be chosen are video conference based on video conferencing-based platforms are the richest applications in conveying messages [34]. Video conferencing is done by scheduling tailored to the needs of students, formed from their interests, and developed from discussions in the form of audio. On this platform, it has a level of control over the presence of lecturers and students in learning activities, exam strategies, and teaching evaluation [35].

Digital platforms such as zoom and Google Meet allow lecturers and students to interact via video which enables the synchronous process of delivering material and achieving discussion. The subject matter is a form of message with high complexity choosing a platform for interaction between lecturers and students, constituting two fundamental elements in the effectiveness of distance learning [36]. However, the results of the study showed that there was less interaction between lecturers and students related to learning material except in terms of giving and billing assignments. The absence of questions and answers related to material or material explanation activities from lecturers is a significant obstacle in the knowledge transfer process, where this is not found during the face-to-face lectures takes place.

The results showed that distance learning using CMC had some advantages: students read more about the material and assignments are given to make the students more independent [37]. Besides, the advantage of using $\mathrm{CMC}$ in distance learning is that it is easy to access the various distance learning platforms used. Thus, it might motivate students to enrich themselves with the material given during distance learning. There are five generalizations of motivation: 1) Adaptive self-efficacy and competency beliefs that motivate students, 2) adaptive attributions and control beliefs motivate students, 3) higher levels of interest and intrinsic motivation motivate students, 4) value levels higher motivates students, and 5) aiming to motivate and direct students [38] [39]. Another advantage is that the achievement of academic goals for both lecturers and students is that they have flexible time and place. Distance learning can be done in different places at the same time. Thus, lecturers and students can do other activities [40].

However, besides the advantages, distance learning using CMC also has weaknesses, i.e. having a dependence on technology and internet networks. Thus, when students cannot operate computer devices and use the platform used in distance learning, distance learning will not run as expected. Moreover, the use of excessive internet data quota during the implementation of distance learning leading to the students to be less engaged during the material delivery. This makes them distracted and less motivated. The distance in distance learning is a big gap in the lecture process. The absence of lecturers and students in the same room causes the interaction through body language is lost and students' perceptions of material and interactions also change [41] [42].

Computer-mediated communication (CMC) changes the nature of human communication interactions from face-toface physically to meeting in a digital space. Accordingly, this pattern change will cause its distortion in terms of conveying meaning in the learning process considering that the process, which was a direct interaction between lecturers and students, becomes communication mediated by computer devices. This will greatly affect the mutual interaction between the two in the process of understanding the material being taught [43]. 
Based on the discussion of the research results above, it can be concluded that the effectiveness of delivering messages through the selection of the media used by taking into account the efficiency of data quota consumption is something that should be considered by all teachers and stakeholders in the realm of educational institutions in Indonesia. Technology mastery is also absolutely should be possessed by every lecturer, in the terms of not only its basic knowledge but also the use of media features to achieve the integrity of the message conveyed without physical face-to-face interaction.

The interaction between lecturers and students also basically has its urgency where the interaction between lecturers and students will have a positive impact on student learning. Therefore, to improve the distance learning system in Higher Education, the researchers provide the following recommendations: 1) There should be a reduction in assignments and an additional time to submit assignments which is slightly extended; 2) The ability of lecturers in delivering material and preparing teaching materials should be increased to achieve the messages or information delivered; 3) The education provider should provide compensation in the form of additional funds in terms of internet data quota; and 4) The right platform in using $\mathrm{CMC}$ during the distance learning should be carefully selected.

\section{Conclusion}

Since COVID 19 has begun to spread in Indonesia on March 2020, there has been a change from traditional education to online education or distance learning using an online platform. One of the media used in distance learning was CMC. However, based on the results obtained, it turns out that the implementation of distance learning using $\mathrm{CMC}$ in universities was still considered ineffective because many factors are required to be met to carry out distance learning properly. There were three factors influencing the implementation of CMC: internal, external, and contextual factors.

\section{ACKNOWLEDGMENT}

Ika Novitaria Marani is a senior lecturer at Universitas Negeri Jakarta, Jakarta. Her research interests include interpersonal communication, customer satisfaction, education, and sports.

Ari Subarkah is a senior lecturer at Universitas Negeri Jakarta, Jakarta. His research interests include distance learning and sports education.

Adi Wijayanto is a senior lecturer at IAIN Tuluganggung, Jawa Timur. His research interests include information technology, learning media, and sports education

\section{REFERENCES}

[1] Www.whitehouse.gov. 03.16.20_coronavirusguidance_8.5x11_315PM.pdf.

[2] Chick RC, Clifton GT, Peace KM, et al. Using Technology to Maintain the Education of Residents During the COVID-19 Pandemic. J Surg Educ. Epub ahead of print 2020. DOI: 10.1016/j.jsurg.2020.03.018.

[3] Cuthell JP. Virtual learning: the impact of ict on the way young people work and learn. 2002.

[4] Inglis, A., Ling, P., \& Joosten V. Delivering digitally: Managing the transition to the knowledge media. 2002.

[5] Zeng G. Collaborative dialogue in synchronous computer-mediated communication and face-to-face communication. ReCALL 2017; 29: 257-275.

[6] Baltes BB, Dickson MW, Sherman MP, et al. Computer-mediated communication and group decision making: A meta-analysis. Organ Behav Hum Decis Process 2002; 87: 156-179.

[7] Zhou L, Zhang D. A comparison of deception behavior in dyad and triadic group decision making in synchronous computer-mediated communication. Small Gr Res 2006; 37: 140-164.

[8] Shu-Chu Sarrina Li. Computer-Mediated Communication and Group Decision Making: A Functional Perspective. Sage Publ; 38: 593-614.

[9] Peterson M. Learner interaction in synchronous CMC: a sociocultural perspective. Comput Assist Lang Learn 2009; 22: 303-321.

[10] Kitade K. L2 Learners' Discourse and SLA Theories in CMC: Collaborative Interaction in Internet Chat. Comput Assist Lang Learn 2010; 143-166.

[11] Thompson EW, Savenye WC. Adult learner participation in an online degree program: A programlevel study of voluntary computer-mediated communication. Distance Educ 2007; 28: 299-312.

[12] Lee GC, Wu CC. Enhancing the teaching experience of pre-service teachers through the use of videos in web-based computer-mediated communication (CMC). Innov Educ Teach Int 2006; 43: 369-380.

[13] Terhune NM. Language learning going global: linking teachers and learners via commercial Skypebased CMC. Comput Assist Lang Learn 2016; 29: 1071-1089.

[14] Lowry PB, Roberts TL, Romano NC, et al. The impact of group size and social presence on small- 
group communication: Does computer-mediated communication make a difference? Small Gr Res 2006; 37: 631-661.

[15] Finegold ARD, Cooke L. Exploring the attitudes, experiences and dynamics of interaction in online groups. Internet High Educ 2006; 9: 201-215.

[16] Ahern TC, Repman J. The effects of technology on online education. J Res Comput Educ 2015; 26: $537-546$

[17] Pendidikan D, Kabupatenl DP, Pendidikan L, et al. Dan Pakai. 2020.

[18] Barker BO, Frisbie AG, Patrick KR, et al. Concepts: Broadening the definition of distance education in light of the new telecommunications technologies Broadening The Definition of Distance Education in Light of the New Telecommunications Technologies. 3647. Epub ahead of print 2016. DOI: $10.1080 / 08923648909526647$.

[19] Bower BL, Hardy KP. From correspondence to cyberspace: Changes and challenges in distance education. New Dir Community Coll 2004; 2004: 5-12.

[20] Moore M, Kearsley G. Distance Education: A System View of Online Learning. 2011. Epub ahead of print 2011. DOI: 10.1016/S0360-1315(99)00024-X.

[21] Roberts JM. The story of distance education: $A$ practitioner's perspective. J Am Soc Inf Sci 1996; 47: 811-816.

[22] Simonson M, Schlosser C. American Journal of Distance Theory and distance education: A new discussion. 2009; 60-75.

[23] Moore MG. Autonomy and interdependence. Am J Distance Educ 2015; 29: 229-231.

[24] Garrison R. Theoretical challenges for distance education in the 21st century: A shift from structural to transactional issues. Int Rev Res Open Distance Learn 2000; 1: 6-21.

[25] Kelsey KD, D'souza A. Student Motivation for Learning at a Distance: Does Interaction Matter? Online J Distance Learn Adm 2004; 7: 2004.

[26] Harasim L. Online education: An environment for collaboration and intellectual amplification. In L. Harasim (Ed.), Online education: Perspectives on a new enviro. New York Praeger 1990; 39-63.

[27] McComb M. Benefits of computer-mediated communication in college courses. Commun Educ 1994; 43: $159-170$

[28] Walther JB. Theories of computer-mediated communication and interpersonal relations. SAGE Handb Interpers Commun 2011; 443-479.

[29] Hui, D. S., E., I. A., Madani, T. A., Ntoumi, F., Kock, R., Dar, O. et al. The continuing 2019-nCoV epidemic threat of novel coronaviruses to global health-The latest 2019 novel coronavirus outbreak in Wuhan, China. Int J Infect Dis 2020; 1: 264-66.

[30] CSSE JH. Coronavirus COVID-19 Global Cases by the Center for Systems Science and Engineering (CSSE) at Johns Hopkins University (JHU). ArcGIS: https://gisanddata.maps.arcgis.com/apps/opsdashboard /index.html\#/bda7594740fd40299423467b48e9ecf6 2020; 222-232.

[31] Marshall AL, Wolanskyj-Spinner A. COVID-19: Challenges and Opportunities for Educators and Generation Z Learners. Mayo Clin Proc 2020; 95: 1135-1137.

[32] Dubey P, Pandey D. Distance Learning in Higher Education during Pandemic: Challenges and Opportunities. Int J Indian Psychol 2020; 8: 43-46.

[33] Lan YF, Sie YS. Using RSS to support mobile learning based on media richness theory. Comput Educ 2010; 55: 723-732.

[34] Cacheiro-Gonzalez ML, Medina-Rivilla $A$, Dominguez-Garrido MC, et al. The learning platform in distance higher education: Student's perceptions. Turkish Online J Distance Educ 2019; 20: 71-95.

[35] Passerini K, Granger MJ. A developmental model for distance learning using the Internet. Comput Educ 2000; 34: 1-15.

[36] Bernard, R. M., Abrami, P. C., Borokhovski, E., Wade, A., Tamim, R., Surkes, M. A. et al. A metaanalysis of three interaction treatments in distance education. Int $J$ Instr Technol Distance Learn; 8. Epub ahead of print 2009. DOI: 2014.10.

[37] Abrami PC, Bernard RM, Bures EM, et al. Interaction in distance education and online learning: Using evidence and theory to improve practice. $J$ Comput High Educ 2011; 23: 82-103.

[38] Zimmerman BJ. Investigating self-regulation and motivation: Historical background, methodological developments, and future prospects. Am Educ Res J 2008; 45: 166-183.

[39] Pintrich PR, De Groot E V. A Motivational Science Perspective on the Role of Student Motivation in Learning and Teaching Contexts. J Educ Psychol 2003; 95: 667-686.

[40] Hamzaee RG. A survey and a theoretical model 
of distance education programs. Int Adv Econ Res 2005; 11: 215-229.

[41] Elareshi M, Alsridi H, Ziani AK. Perceptions of online academics' and Al-Jazeera.Net's news coverage of the Egyptian political transformation 2013-2014. J Komun Malaysian J Commun 2020; 36: 124-146.

[42] Fulford CP, Zhang S. Perceptions of Interaction: The Critical Predictor in Distance Education. Am J Distance Educ 1993; 7: 8-21.

[43] Gunawardena CN, Zittle FJ. Social presence as a predictor of satisfaction within a computer-mediated conferencing environment. Int J Phytoremediation 1997; 21: $8-26$.

[44] Koehler AA, Newby TJ, Ertmer PA. Examining the Role of Web 2.0 Tools in Supporting Problem Solving During Case-Based Instruction. J Res Technol Educ 2017; 49: 182-197. 